\title{
Satisfaction and Behavioural Intentions of Congress Attendees: Evidence from an International Congress in Novi Sad [Serbia]
}

\author{
Dragićević VanjaA*, Blešić IvanaA, Stankov UglješaA \\ Received: September 2009 | Revised: January 2010 | Accepted: January 2010
}

\begin{abstract}
The congress industry, as a part of business tourism sector, is globally recognized for its valuable economic contribution to tourism destinations. Regardless economic benefits, there are as well as numerous social, cultural and environmental benefits that congress industry brings to destinations. This is the reason why the congress industry is becoming one of the fastest growing sectors of tourism industry. At the same time, the congress destinations worldwide are competing in bidding international congresses.

According to the Strategy of Tourism Development of the Republic of Serbia [2005], congress tourism is recognized as a quick win product that could contribute in a short period of 3 to 5 years to tourism development and image of Serbia. The cities of Belgrade, Novi Sad and Niš are identified as the congress destinations capable for hosting international congresses.

Novi Sad, as administrative, economic, cultural, scientific and educational centre of the region of Vojvodina [northern part of Serbia] and known as "town of fairs" [it has long tradition in organizing fairs - since 1923] has strong potential for smaller international congresses.

In order to improve quality of "congress" tourist product, provide stability of congress destination and congress centres, it is necessary to understand meeting planners' and congress attendees' levels of satisfaction and reaction to their experience in destination. In Serbia there is no research regarding mentioned items. The aim of this paper is to examine and analyze the perspective of the congress attendees, as they are final consumers of congress tourist product and their experience and behavioural intentions regarding Novi Sad is thus essential to destination marketing and management organizations, congress centre, hotel managers and meeting planners.
\end{abstract}

Key words: satisfaction, behaviour, congress attendees, Novi Sad

\section{Introduction}

Congress tourism is a major segment of the international tourism market and of economic significance to many countries worldwide. Congresses are part of the business tourism (or business events) sector, a major though often undervalued sector of the wider tourism industry (Rogers, 2006). WTO (2007) considers meetings, incentives, conventions and exhibitions as the key components of business tourism. Of the total international arrivals in 2005, I6\% (I25 million trips) were attributable to business tourism (WTO, 2006).
Business tourism is concerned with people travelling for purposes which are related to their work (Davidson, Cope, 2003). The term business tourism comprises all aspects of the experience of the business traveller who stay away from home for at least one night (Swarbrooke, Horner, 200I). According to Chaspoule (200I), business tourism or tourisme d'affaire (in French) concerns only voyages in alliance with congresses, conventions or seminaries. Getz (2008) considers business events, including meetings, conventions and exhibitions, as a part of event tourism. An alternative term be-

A University of Novi Sad, Faculty of Science, Department of Geography, Tourism and Hotel Management; Trg Dositeja Obradovića 3, 21000 Novi Sad, Serbia, www.dgt.uns.ac.rs

* Corresponding author: Vanja Dragićević, e-mail: vanja.dragicevic@dgt.uns.ac.rs;

Co-authors: Ivana Blešić, e-mail: ivana.blesic@dgt.uns.ac.rs; Uglješa Stankov, e-mail: ugljesa.stankov@dgt.uns.ac.rs 
ing used increasingly to describe some of business tourism sectors is the MICE industry, an acronym for meetings, incentives, conventions (conferences or congresses) and exhibitions (events). Davidson and Cope (2003) and Rogers (2006) agree that this acronym is not adequate term to describe one of the major and growing sector of the wider tourism industry.

The expressions used to describe meetings (conferences, congresses, conventions) are often used synonymously. However, the only real difference can be found in the number of participants and the location of the event. Conferences are usually on a smaller scale than congresses (Ladkin and Spiller 2000). The expression "conference" does seem to include the same as does "congress" and "convention", especially in terms of UK-usage. In America, Australia and Asia the term "convention" is used for the same purpose as conference. In much of mainland Europe a large meeting is usually called a congress (Swarbrooke, Horner, 200I). However, what makes a meeting as a part of business tourism is that it engages some of the services of the tourism industry and is usually held away from the premises of the organisation running it (Davidson, I994).

Although there are some differences in terminology and typology of congress tourism among authors, they agree that the congress industry, as a part of business tourism sector, is globally recognized for its valuable economic contribution to tourism destination. Congress tourism is also associated with other benefits of a more intangible nature (social and cultural benefits to the destination, the exchange of ideas, the cultivation of business contacts, the provision of forums for continuing education and training, facilitation of technology transfers) (Weber, Chon, 2002). On the supply side, destinations develop, facilitate and promote events of all kinds to meet multiple goals: to attract tourists (especially in the off-peak seasons), serve as a catalyst (for urban renewal, and for increasing the infrastructure and tourism capacity of the destination), to foster a positive destination image and contribute to general place marketing. From the tourism industry's perspective, events are highly valued as attractions, catalysts, animators, place marketers, and image-makers. Interest in the tourism value of business events, including meetings, conventions and exhibitions has been intense for so long that almost all major cities now possess impressive convention and exhibition facilities (Getz, 2008). Congress attendees are valuable assets for the tourism industry. Their attendance benefits both congress organizers and host locations. They bring multi-economic benefits to the host location through their expenditure on accommodation, food and beverages, local transportation and miscellaneous spending (Oppermann \& Chon, 1997). They usually stay longer and spend more than other types of tourists. With their favourable word-of-mouth comments, they help in promoting tourism in the host location by giving it a positive image. Furthermore, congress attendees can provide a major source of shoulder and off-season demand, since most corporate and association meetings take place during the spring and fall, the traditional soft periods in many tourist areas (Oppermann, I996; Zhanga, Leunga, Qu, 2007).

Due to direct economic impacts, stimulation of investments, the prestige that can result from hosting a congress, environmental enhancement, local business development and many other benefits of congress tourism for the local communities, the number of congress tourism destinations worldwide constantly grows.

According to the Strategy of Tourism Development of the Republic of Serbia (2005), business tourism is recognized as a quick win product that could contribute in a short period of 3 to 5 years to tourism development and image of Serbia. Serbia does not currently have a robust international congress business. At how many international congresses are listed as being scheduled in the years $2004-2015$, Serbia ranks 47 th overall in ICCA category, with a total of $0,2 \%$ of the meetings, while countries in the region (Hungary, Slovenia, Croatia, Romania) are in better position (Grimmer, 2005). Serbian Congress Bureau, formed in 2006, promotes primary cities of Belgrade and Novi Sad as congress (meeting) destinations that have facilities for attracting international meetings.

Competition among congress destinations and venues has highlighted the need for better understanding of the congress attendee behaviour, including their decision-making and their evaluation of the congress experience (PCMA Survey, 2003). Congress attendee satisfaction assessment is fundamental to the well-being of attendees, to the profits of hotels and congress centres hosting congresses, and to the stability of destinations and congress centres (Oliver, I996). Satisfaction of congress attendees is critical in determining congress loyalty and includes behavioural intentions regarding next year's return and whether or not to recommend the destination to others. Severt, Wang, Chen \& Breiter (2007) examined the motivation, perceived performance, and behavioural intentions of convention attendees. They were the first to test the conceptual model in the convention industry from the attendee's viewpoint, which examines the relationships between the attendees' evaluation of conference performance, satisfaction level, and behavioural intention rela- 
tive to the conference. The research showed that those attendees, who reported a stronger satisfaction with the convention, were more likely to return and to tell others to attend the conference. Strong performance is not enough to guarantee a return but gives a much higher chance than poor performance. These findings have been supported by numerous studies confirming that satisfaction leads to favourable word-of-mouth and the image of destination.

In Serbia there is no research about the satisfaction of meeting planners with destination choice, nor about the perception, level of satisfaction and behavioural intentions of congress attendees. It's not surprising, having in mind that congress industry in Serbia is still in its infancy and that the Tourist Organization of Serbia, with Serbian Congress Bureau, and all interested entrepreneurs have recently started to affirm congress industry and to promote Serbia as a meeting destination.

This study represents a pilot research and takes the perspective of the congress attendees and examines a series of issues about their satisfaction and evaluation of the congress performance.

\section{Congress Tourism in Novi Sad}

Congress tourism is in last few years recognized as one of the most important parts of tourism industry in Novi Sad as well as in other parts of Serbia. Novi Sad, as administrative, economic, cultural, scientific and educational centre of the region of Vojvodina (northern part of Serbia) and known as "town of fairs" (it has long tradition in organizing fairs - since I923) has strong potential for smaller international conferences. In 2006 Novi Sad Fair opened a new congress centre Master, capable for hosting up to 4,00o congress attendees and started to affirm congress industry in Novi Sad and in whole region of Vojvodina. The Novi Sad Fair also offers some 60,000 SQM of indoor exhibit space. At the same time, hotel "Park", renovated into fivestar hotel (in that time it was the only five-star hotel in Vojvodina), also, opened up-to-date congress centre with capacity of 1200 seats.

Novi Sad University also provides an opportunity as its Agriculture school is one of the most respected in Europe. It is strong in the fields of genetic research, medicine, environmental sciences and engineering. In addition, SPENS (Sport and Business Center) is the largest sports centre in Europe and one of the three largest in the world. SPENS is host to major international championships in bowling, basketball, karate, volleyball and Davis Cup Tennis. This represents another congress opportunity for Novi Sad, as there are many sports related associations that hold congresses and would be interested in meeting there.
In 2007, 94.934 tourists spent I79.719 nights in Novi Sad. The reasons of visits are mostly business related. Blešić, Wallranbestein and Dević (2008) examined the motivation of Novi Sad visitors out of tourist season and they found that the most important motives, for both domestic and foreign visitors, in the period of low season, are business related (business meetings and cooperation, meeting new people and making new contacts) and the main "pull" factor (factor that attracts visitors) is presented in seminars, congresses, trainings and business.

The biggest concentration of tourists in Novi Sad is in May and October, when Novi Sad Fair is the host of international and traditionally organized exhibitions, which every year attract great number of visitors and exhibitors from country and abroad. In 2007 Novi Sad Fair had I,200,000 visitors. From its opening (September 2006) by the end of 2008, more than 500 meetings, with 60.000 attendees from 60 countries worldwide, were held in Congress Centre Master. Unfortunately, congress centre of hotel "Park" wasn't so successful in bidding international conferences. In the structure of guests of this hotel, the most dominant are individual business people, meanwhile the number of attendees of meetings organized in hotel's congress centre is irrelevant.

Novi Sad has necessary congress facilities for hosting large international congress, but the success and the image of Novi Sad as a congress destination also depends on congress attendees viewpoint. The authors of this paper, in cooperation with hotel "Park" marketing sector, conducted a pilot research, during the international congress organized by the Institute for Food Technologies from Novi Sad and International Feed Industry Federation, in order to examine congress attendees satisfaction with the congress performance and destination as well as their behavioural intentions associated with Novi Sad as the congress destination.

\section{Methodology}

A questionnaire survey was used as an instrument for the study. The study instrument was developed after an in-depth literature review on the topics related to convention, meeting, and conference attendance behaviour. The questionnaire consists of four parts. The first part of the instrument consists of basic socio-demographic characteristics of a respondent (gender, age, country of origin, level of education). The second part points out the source of information about the congress. The third part comprises 5 questions about respondent's behaviour during stay in Novi Sad (length of stay, type of accommodation, arrived at congress 
alone, with spouse or with colleagues, spending). Satisfaction of the respondents with the performance of congress and their behavioural intentions referring to Novi Sad are examined in the fourth part of questionnaire. The respondents expressed opinions on the level of their satisfaction of cited elements of the congress using a five-point Likert scale, ranging from "very satisfied" (5) to "very dissatisfied" (I).

Attendees at an international congress, produced by a national institute and international association, were used as the sampling frame for this study. The congress was supported by The Ministry of Science of the Republic of Serbia, Provincial Secretariat for Science and Technological Development, Ministry of Agriculture, Forestry and Water Management of the Republic of Serbia, Serbian Chamber of Commerce, Chamber of Commerce of Vojvodina and Regional Chamber of Commerce of Novi Sad.

The congress was held at hotel "Park" congress centre in Novi Sad (Serbia). A simple random sampling approach was used to select sample. The congress attendees were approached and invited to take part in the data collection process on a voluntary basis. The congress expected 200 attendees which was the population for the study. Data collection was conducted last day of the 3-day congress. The interception location (hotel lobby) for data collection was decided based on discussions with the congress manager. Our successful interceptions resulted in 58 usable surveys. The

Table 1 Profile of the respondents

\begin{tabular}{|c|c|c|c|c|}
\hline & Frequency & $\%$ & Valid \% & Cumulative \% \\
\hline \multicolumn{5}{|l|}{ Gender } \\
\hline male & 25 & 43,1 & 43,1 & 43,1 \\
\hline female & 33 & 56,9 & 56,9 & 100,0 \\
\hline Total & 58 & 100,0 & 100,0 & \\
\hline \multicolumn{5}{|l|}{ Age } \\
\hline $25-35$ & 30 & 51,7 & 51,7 & 51,7 \\
\hline $36-50$ & 21 & 36,2 & 36,2 & 87,9 \\
\hline over 50 & 7 & 12,1 & 12,1 & 100,0 \\
\hline Total & 58 & 100,0 & 100,0 & \\
\hline \multicolumn{5}{|l|}{ Education } \\
\hline high school & 1 & 1,7 & 1,7 & 1,7 \\
\hline faculty & 35 & 60,3 & 60,3 & 62,1 \\
\hline MSc, PhD & 22 & 37,9 & 37,9 & 100,0 \\
\hline Total & 58 & 100,0 & 100,0 & \\
\hline \multicolumn{5}{|l|}{ Origin } \\
\hline Europe & 10 & 17,3 & 17,3 & 17,3 \\
\hline Serbia & 46 & 79,3 & 79,3 & 96,6 \\
\hline USA & 2 & 3,4 & 3,4 & 100,0 \\
\hline Total & 58 & 100,0 & 100,0 & \\
\hline
\end{tabular}

data was analyzed using Statistical Packages for Social Sciences (SPSS).

\section{Study results}

The study results reported focus on the following areas: the profile of the respondents, the behaviour of the respondents during stay in Novi Sad, performance evaluation of the congress, and the relationship between performance, satisfaction, and behavioural consequences.

\section{Profile of respondents}

The sample taken for this research consists of 58 respondents. Among them 33 (56.9\%) are males, and $25(43.1 \%)$ are females, with most of them $(87.9 \%)$ between the ages of 25 and 50. Only I2.I\% of respondents are over 50.

By their education level, respondents holding a university degree are dominant making total of 60.3\%, followed by MSc and PhD degree (37.9\%), whereas only I respondent (I.7\%) has high school degree.

In terms of their origin, majority of respondents $(79.3 \%)$ are from Serbia, whereas foreign attendees come mostly from Europe (17.3\%). Also, two respondents (3.4\%) from USA took part in this research.

\section{The source of information about the congress}

Almost two third of the respondents (65.5\%) got information about the congress from friends or business associates, 31\% of the respondents received invitation letter from the organizers, meanwhile only $3.4 \%$ of the respondents reported that they had found information about the congress on the Internet. As expected, these results show the importance of word-of-mouth in the congress industry, but also, point out to the Internet as a significant promotional tool, which in this case wasn't used enough by meeting organizer.

\section{The behaviour of the respondents during stay in Novi Sad}

In this paragraph, four elements of the respondents' behaviour will be reported and analyzed: length of stay, type of accommodation, arrived at congress alone, with spouse or with colleagues and spending. The respondents from Novi Sad and its surroundings (Io respondents) were excluded from this part of the research, as they are residents of Novi Sad.

The attendees of 3-day international congress included in this research spent at least two days in Novi Sad, while the longest reported stay was 4 day. The average length of stay was 2.69 days. A little more than one-third of total respondents 
(39.7\%) spent 2 days in Novi Sad, $29.3 \%$ of respondents reported stay of 3-day, meanwhile only I3.8\% of respondents spent 4 days in Novi Sad

In terms of accommodation, slightly less than one-third of the respondents (31\%) claimed that they stayed at hotel "Park" (the venue of congress), whereas only one respondent stayed at four star hotel near hotel "Park". The respondents who used some other types of accommodation available in Novi Sad (such as hostels, apartments) make 36.2\% of total sample, whereas I3.8\% of the respondents stayed at relatives or friends in Novi Sad.

The largest percentage of the respondents (41.4\%) attended congress with colleague/s, followed by $22.4 \%$ of the respondents arrived with spouse and $19 \%$ of the respondents who came alone in Novi Sad.

During the stay in Novi Sad, the majority of the respondents (77.6\%) spent 50 Euro or less a day, while only $5.2 \%$ of the respondents spent $5 \mathrm{I}-\mathrm{IOO}$ Euro a day, mostly on food and drink, shopping and souvenirs.

\section{Performance evaluation of the congress and behavioural consequences}

The respondents were also asked to evaluate three elements of congress performance (the venue, the organization of congress and available technical equipment). Regarding their personal satisfaction, the respondents validated each of cited elements using a five-point Likert scale, with " $\mathrm{I}$ " indicating very dissatisfied to " 5 " indicating very satisfied. The mean and standard deviation of the evaluation items, as well as minimum and maximum value, are reported in Table 3.

As can be seen from Table 3, all the elements received the average score higher than 4 (4 - satisfied). In an expectant manner, the respondents estimated all the elements of the congress about their satisfaction as satisfactory on average. The "venue" element received the highest score of the respondents' satisfaction among all the elements $(M=4.64)$. More than two third of the respondents (74.I\%) reported they were very satisfied with the venue of the congress, whereas only $3.4 \%$ of the respondents were dissatisfied (Table 4). Such high percentage of very satisfied respondents, with the average score higher than $4(\mathrm{M}=4.3 \mathrm{I})$ for the element "technical equipment", supports the fact that hotel "Park" with its congress centre is a convenient location for holding international meetings.

In terms of the organization of congress, $50 \%$ of the respondents claimed that they were very satisfied, while slightly less than one third of the respondents (32.8\%) were satisfied.

To examine if certain groups of respondents differ according to their level of satisfaction with
Table 2 The main source of information about the congress for the respondents

\begin{tabular}{|l|r|r|r|r|}
\hline Source of information & Frequency & \multicolumn{1}{c|}{$\%$} & Valid \% & Cumulative \% \\
\hline Internet & 2 & 3,4 & 3,4 & 3,4 \\
\hline $\begin{array}{l}\text { Friend/Business } \\
\text { associate }\end{array}$ & 38 & 65,5 & 65,5 & 69,0 \\
\hline Invitation letter & 18 & 31,0 & 31,0 & 100,0 \\
\hline Total & 58 & 100,0 & 100,0 & \\
\hline
\end{tabular}

Table 3 Respondents' satisfaction with the elements of congress

\begin{tabular}{|l|r|r|r|r|}
\hline Elements of congress & Minimum & Maximum & Mean & Std. Deviation \\
\hline Venue & 2 & 5 & 4,64 &, 718 \\
\hline Organization & 2 & 5 & 4,28 &, 874 \\
\hline Technical equipment & 3 & 5 & 4,31 &, 799 \\
\hline
\end{tabular}

Table 4 The degree of respondents' satisfaction with the elements of congress

\begin{tabular}{|l|r|r|r|}
\hline \multirow{2}{*}{$\begin{array}{l}\text { Level of } \\
\text { Satisfaction }\end{array}$} & \multicolumn{3}{|c|}{ Frequency of respondents [\%] } \\
\cline { 2 - 4 } very dissatisfied & \multicolumn{1}{|c|}{ venue } & organization & technical equipment \\
\hline dissatisfied & 3,4 & - & - \\
\hline neutral & 3,4 & 5,2 & - \\
\hline satisfied & 19,0 & 12,1 & 20,7 \\
\hline very satisfied & 74,1 & 32,8 & 27,6 \\
\hline Total & 100,0 & 50,0 & 51,7 \\
\hline
\end{tabular}

the congress performance, the authors divided the respondents into groups according to age, level of education, origin and gender.

Regarding their age, the respondents were divided into three groups: $25-35,36-50$ and over 50 years. Using the One-Way ANOVA method for investigation of significance of mean value differences, it may be concluded with $95 \%$ accuracy that, between three groups of respondents of different age, there are no statistically significant dissimilarities in the level of respondents' satisfaction with the congress venue $(\mathrm{F}=\mathrm{I} .958 ; \mathrm{df}=2$; Sig. $=\mathrm{I} .5 \mathrm{I})$, with the organization of congress $(\mathrm{F}=0.139 ; \mathrm{df}=2$; Sig.=0.87), nor with the technical equipment ( $F=0.419 ; \mathrm{df}=2 ;$ Sig. $=0.659)$.

Also, One-Way ANOVA was applied for investigation of differences between three groups of respondents according to their education level. Results in Table 5 show that there is no statistically significance between groups of respondents regarding their level of satisfaction with all cited elements of the congress.

In addition, t-test was used for testing differences in mean satisfaction between the respondents regarding their gender and, also, their origin. The results indicate that there are no statistical- 
Table 5 Compare Means - One-Way ANOVA. Dependent List: venue, organization and technical equipment. Factor: educational level of the respondents

\begin{tabular}{|c|c|c|c|c|c|c|}
\hline Dependent List & & Sum of Squares & $\mathrm{df}^{*}$ & Mean Square & $\mathrm{F}^{* *}$ & Sig. ${ }^{* * *}$ \\
\hline \multirow{3}{*}{ Venue } & Between Groups & 847 & 2 & .424 & 816 & .447 \\
\hline & Within Groups & 28,549 & 55 & ,519 & & \\
\hline & Total & 29,397 & 57 & & & \\
\hline \multirow{3}{*}{ Organization } & Between Groups & .642 & 2 & 321 & .411 & 665 \\
\hline & Within Groups & 42,944 & 55 & ,781 & & \\
\hline & Total & 43,586 & 57 & & & \\
\hline \multirow{3}{*}{$\begin{array}{l}\text { Technical } \\
\text { equipment }\end{array}$} & Between Groups & 924 & 2 &, 462 & ,716 & .493 \\
\hline & Within Groups & 35,490 & 55 & 645 & & \\
\hline & Total & 36,414 & 57 & & & \\
\hline
\end{tabular}

${ }^{*}$ df [divisions of sums of squares' deviations]; ** F [value F statistics]; *** Sig. [significance of F statistics - if lower than $0.05-t$ there is $95 \%$ of certainty that there is statistically significant difference between the groups]

ly relevant differences in mean satisfaction by the elements of congress performance between two groups of respondents of different gender (for "the

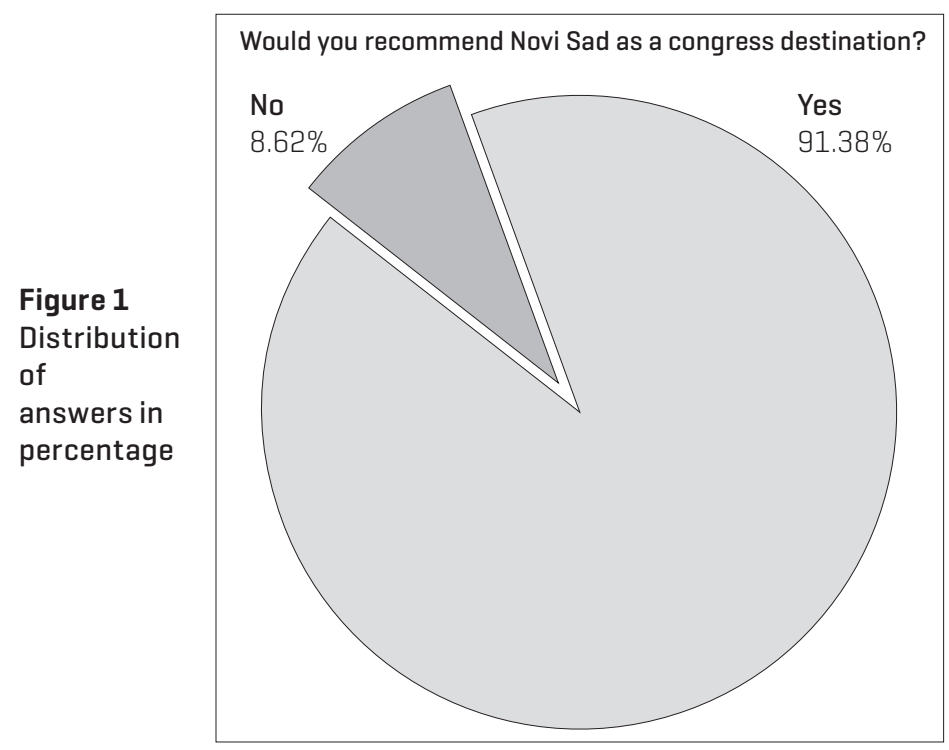

venue" element $\mathrm{t}=\mathrm{I} . \mathrm{I29}, \mathrm{df}=56$, Sig. $=0.264$; for "the organization" element $\mathrm{t}=-0.270, \mathrm{df}=56, \mathrm{Sig} .=0.788$; for "technical equipment" element $\mathrm{t}=-0.25 \mathrm{O}, \mathrm{df}=56$, Sig.=0.804).
Regarding their origin, the respondents were divided into two groups: domestic and foreign respondents. From the results of t-test (Table 6), it can be concluded that there are no statistically relevant differences in mean satisfaction between domestic and foreign respondents.

From the interpreted results, the conclusion may be drawn that respondents, regardless the age, level of education, gender and origin, do not significantly differ regarding level of satisfaction with the venue of the congress, the organization and technical equipment, and that the respondents mainly feel satisfied with the congress performance.

The two last questions of the study addressed respondents' behavioural consequences: intention to return and intention to recommend Novi Sad as a congress destination. On the question "Would you like to visit Novi Sad again?" all 48 respondents answered affirmative and as reasons they cited sightseeing, cultural motives, hospitality of local residents, and, in case of domestic respondents, visiting friends and relatives.

Most of the respondents (91.38\%) would recommend Novi Sad as a destination for holding congress because of up-to-date congress facilities, high-quality accommodation facilities, cultural

Table 6 Compare Means - T-Test Independent Samples Test. Test Variables: venue, organization and technical equipment. Grouping Variable: origin of the respondents

\begin{tabular}{|c|c|c|c|c|c|c|}
\hline \multirow{2}{*}{ Test Variables } & & \multicolumn{5}{|c|}{ t-test for Equality of Means } \\
\hline & & $\mathrm{t}^{* *}$ & $d f *$ & Sig. [2-tailed] ${ }^{* * *}$ & Mean Difference & Std. Error Difference \\
\hline \multirow{2}{*}{ Venue } & Equal variances assumed &,- 188 & 55 & 852 &,- 044 & ,237 \\
\hline & Equal variances not assumed &,- 203 & 19,480 & 841 &,- 044 & 219 \\
\hline \multirow{2}{*}{ Organization } & Equal variances assumed &,- 530 & 55 &, 598 &,- 150 & ,283 \\
\hline & Equal variances not assumed &,- 635 & 23,268 & 532 &,- 150 & ,236 \\
\hline \multirow{2}{*}{$\begin{array}{l}\text { Technical } \\
\text { equipment }\end{array}$} & Equal variances assumed & .410 & 55 & 684 & ,106 & , 258 \\
\hline & Equal variances not assumed & ,383 & 15,994 & ,706 & ,106 & ,275 \\
\hline
\end{tabular}

${ }^{*} \mathrm{df}$ [divisions of sums of squares' deviations]; ${ }^{* *} t$ [value t statistics]; ${ }^{* * *}$ Sig. [2-tailed] [significance of $t$ statistics - if lower than $0.05-$ there is $95 \%$ of certainty that there is statistically significant difference between the groups] 
and historic attractions, hospitality of local residents, lower prices in comparison with other congress destinations in the region and safety.

According to these results, most respondents were satisfied with their travel and congress experience in Novi Sad. Also, these results confirm that Novi Sad has a great potential for development of congress tourism.

\section{Conclusion}

According to the Strategy of Tourism of the Republic of Serbia (2005), business tourism is considered as one of the priorities in the country tourism development, as it could improve current position of Serbia on Europe and on the world tourism market and it could contribute to promotion of Serbian tourist offer. Belgrade, Novi Sad and Niš are recognized as primary congress tourism destinations, as these cities have necessary infrastructure for holding meetings and they represent attractive tourist destinations. From 2006, when Novi Sad Fair and hotel "Park" opened modern congress centres, the affirmation of congress tourism started. Since then, it has been recording the increase in the number of meetings, conferences, congresses, as well as the number of visitors in Novi Sad, particularly foreign visitors.

To continue this tendency in the future and to provide quality congress tourist product, it is important for destination management organizations, hotels and congress centres hosting congresses, to conduct studies with the aim to examine congress attendees' satisfaction and behavioural intentions.

The research interpreted in this paper about the congress attendees' satisfaction and behavioural intentions, was conducted in hotel "Park" congress centre, on accidental sample, consisting of the international congress attendees, who voluntary took part in the research. Based on the results obtained in analysis of the satisfaction with the congress elements, it is obvious from the mean score (more than 4 - satisfied for all the elements of the congress), that the attendees showed high level of satisfaction. Behavioural intentions of congress attendees regarding Novi Sad as a congress tourist destination were studied by examining two variables: word-of-mouth behaviour and intention to return. The results show that all respondents would like to visit Novi Sad again and as the answer on "Why" question they mentioned cultural heritage, sightseeing, hospitality etc. Also, the majority of the respondents would recommend Novi Sad as a meeting destination. Based on the results of respondents' future behaviour analysis, the conclusion may be drawn that respondents were satisfied with destination choice. As mentioned already, the relationship between consumer satisfaction and behavioural intentions exists. This research, as well as many other studies, confirms that consumer satisfaction leads to favourable word-of-mouth and might lead to repeat visit to a destination.

The limitation of this research is that it was conducted once at an international congress organized for the first time. However, the results of this study are valuable for congress centre managers in Novi Sad and for destination management organizations.

Congress attendees satisfaction assessment is fundamental to the stability of congress destinations and congress centres. Similar studies, about experience, satisfaction, behavioural intentions of congress attendees and meeting planners, should be undertaken periodically in hotels and congress centre in Novi Sad, to improve quality of services, improve competitiveness and effectively promote Novi Sad as a congress destination.

\section{Acknowledgements}

This paper is a part of project "Loess plateaus in Serbia (no. I460I9)" financed by the Ministry of Science of the Republic of Serbia.

\section{References}

Blešić, I., Wallranbestein, K. and Dević, M. 2008. Motivation of Novi Sad (Vojvodina, Serbia) Visitors out of the Tourist Season. Geographica Pannonica I2,I, 45-52.

Chaspoule, C., 200I. Tourisme de Congrès un marché en mutation - Editorial. Espace Tourisme et Loisirs I84, I9-43.

Davidson, R. I994. Business Travel, Addison Wesley Longman.

Davidson, R., Cope, B. 2003. Business Travel - Conferences, Incentive Travel, Exhibitions, Corporate Hospitality and Corporate Travel, Pearson Education.

Getz. D. 20o8. Event tourism: Definition, evolution and research. Tourism Management 29, 403-328.

Grimmer, G. 2005. A Plan for the Establishment of the Serbia Convention Bureau, Serbian Enterprise Development Project (SEDP) - a program funded by USAID.

Ladkin, A. and Spiller, J. 20oo. The Meetings, Incentives, Conferences and Exhibitions Industry. London: Travel and Tourism Intelligence.

Oliver, R. L. I996. Satisfaction: A behavioural perspective on the consumer. McGraw-Hill Publishing Company.

Oppermann, M. I996. Convention destination images: Analysis of association meeting plan- 
ners' perceptions. Tourism Management I7(3), 75-182.

Oppermann, M. and Chon, K. S. I997. Convention participation decision-making process. Annals of Tourism Research, 24,I, I78-I9I.

PCMA. 2003. Professional Convention Management Association Annual Survey.

Rogers, T. 2006. Conferences and Conventions: A Global Industry, Butterworth-Heinemann.

Severt, D., Wang, Y., Chen, P. and Breiter, D. 2007. Examining the motivation, perceived performance and behavioral intentions of convention attendees: Evidence from a regional conference. Tourism Management 28, 399-408.
Swarbrooke, J. and Horner, S. 20oI. Business Travel and Tourism, Butterworth-Heinemann

The Strategy of Tourism Development of the Republic of Serbia 2005.

Weber, K. and Chon, K. 2002. Convention tourism international research and industry perspectives, Haworth Press Inc.,U.S.

WTO. 2006. Tourism highlights 2006 edition. http://www.unwto.org/facts/menu.html.

WTO. 2007. A practical guide to tourism destination management.

Zhanga H. Q., Leunga V. and Qu H. 2007. A refined model of factors affecting convention participation decision-making. Tourism Management 28, II23-II27. 